\title{
An Optimum Dose of Olive Leaf Extract Improves Insulin Receptor Substrate-1, Tyrosine Kinase, and Glucose Transporters, While High Doses Have Genotoxic and Apoptotic Effects
}

\author{
Abdurrahim Kocyigit1,2*, Burçin Kasap1, Eray Metin Guler1,2, Humeyra Nur Kaleli³, \\ Mustafa Kesmen4, Murat Dikilitas' ${ }^{4}$, Ersin Karatas 6 \\ ${ }^{1}$ Department of Medical Biochemistry, Medical Faculty, Bezmialem Vakif University, Istanbul, Turkey \\ ${ }^{2}$ Traditional and Complementary Medicine Advanced Research and Application Center (GETAMER), \\ Bezmialem Vakif University, Istanbul, Turkey \\ ${ }^{3}$ Department of Molecular Biology, Genetics, and Bioengineering, Sabanci University, Istanbul, Turkey \\ ${ }^{4}$ Republic of Turkey Ministry of Agriculture and Forestry Istanbul Pendik Veterinary Control Institute, Istanbul, Turkey \\ ${ }^{5}$ Department of Plant Protection, Agricultural Faculty, Harran University, S. Urfa, Turkey \\ ${ }^{6}$ Department of Molecular Biology and Genetics, Gebze Technical University, Kocaeli, Turkey \\ Email: *akocyigit@bezmialem.edu.tr
}

How to cite this paper: Kocyigit, A., Kasap, B., Guler, E.M., Kaleli, H.N., Kesmen, M., Dikilitas, M. and Karatas, E. (2019) An Optimum Dose of Olive Leaf Extract Improves Insulin Receptor Substrate-1, Tyrosine Kinase, and Glucose Transporters, While High Doses Have Genotoxic and Apoptotic Effects. American Journal of Plant Sciences, 10, 1933-1948.

https://doi.org/10.4236/ajps.2019.1011136

Received: September 3, 2019

Accepted: November 3, 2019

Published: November 6, 2019

Copyright (อ 2019 by author(s) and Scientific Research Publishing Inc. This work is licensed under the Creative Commons Attribution International License (CC BY 4.0).

http://creativecommons.org/licenses/by/4.0/ (c) (i) Open Access

\begin{abstract}
Type 2 diabetes is the most common type of diabetes. Conventionally many drugs are used for the treatment of diabetes such as biguanides, sulfonylureas, meglitinides, etc. But the desired effective treatment is still not to be achieved. So researches are going on for the development of effective alternative therapy against diabetes. Olive leaves are traditionally used in the treatment of the disease. However, studies on its mechanism of action are not yet enough. The aim of this study was to investigate whether olive leaf extract (OLE) improves insulin receptor substrate-1 (IRS-1), tyrosine kinase (TK), GLUT-2, and GLUT-4. Oleuropein levels were analyzed from OLE obtained by using four different solvents, and the highest content of methanol extract was selected for the study. Different concentrations of OLE ( 2.5 to $320 \mu \mathrm{g} / \mathrm{mL}$ ) were incubated with hepatocellular carcinoma (HepG2) cells for 24 hours. After incubation, cell viability was assessed based on luminometric ATP cell viability assay kit. Intracellular reactive oxygen species (ROS) generating level was detected using 2,7dichlorodihydrofluorescein-diacetate $\left(\mathrm{H}_{2} \mathrm{DCF}-\mathrm{DA}\right)$ fluorescent probes. Apoptosis was evaluated by acridine orange/ethidium bromide double staining method. Genotoxicity was evaluated by alkaline single cell gel
\end{abstract}


electrophoresis assay (Comet Assay). Protein expression levels of IRS-1, TK, GLUT-2, and GLUT- 4 were analyzed by western blotting technique from the obtained cell lysates. Although an optimum doses of OLE $(10 \mu \mathrm{g} / \mathrm{mL}) \max -$ imally increased cell proliferation, decreased ROS generation improved IRS-1, TK, GLUT-2, and GLUT-4 protein expression levels (about fivefold), higher doses (10 to $320 \mu \mathrm{g} / \mathrm{mL}$ ) markedly decreased the cell viability, increased DNA damage, apoptosis and ROS generation in a concentration-dependent manner. OLE can be used in the treatment of type 2 diabetes. However, in order to find the most effective and non-toxic concentration, dose optimization is required.

\section{Keywords}

Phytotherapy, Diabetes Mellitus, Olive Leaf Extract, Glucose Transporters, Insulin Receptors

\section{Introduction}

Diabetes is a metabolic disorder which is mainly characterized by hyperglycemia and arises by the defects in insulin secretion or insulin action or both. It is categorized into two types, type-I, and type-II diabetes. It is a common public health problem around the world, and more than $90 \%$ of patients with diabetes are type 2 diabetes mellitus (T2DM) [1]. The global prevalence of DM in adults was estimated to be $8.8 \%$ in 2015 and is predicted to rise to $10.4 \%$ in 2040 [2]. An unhealthy diet and a sedentary lifestyle are important roles in the development of T2DM [3]. It is characterized by disorders of carbohydrate, lipid and protein metabolism, impaired insulin secretion, insulin resistance, or a combination of both [4]. The main metabolic problem in insulin-resistant T2DM is a defect in glucose uptake due to inaccurate regulation of the glucose transporter proteins (GLUT) [5]. An inhibition of tyrosine phosphorylation of insulin receptor substrate-1 (IRS-1) causes GLUT protein defects [5] [6].

T2DM is a disease that can be treated successfully, even if it is not fully cured. Lifestyle changes, such as diet and exercise, may facilitate the treatment of T2DM, but there is a need for anti-diabetic agents to regulate blood sugar levels in severe cases. Conventionally many drugs are used for the treatment of diabetes such as biguanides, sulfonylureas, meglitinides, etc. But the desired effective treatment is still not to be achieved. So researches are going on for the development of effective alternative therapy against diabetes. Medicinal plants are promising source and also very useful for the development of complementary therapy. For example, Subash-Babu et al. [7] demonstrated by an in vitro study that Nymphaea stellata extract increased glucose uptake and glucose-induced insulin secretion and they also showed by an in vivo study that it increased IRS-1 phosphorylation and GLUT-4 expression, which increased insulin response in liver and muscle in T2DM. The protective effects of Astragalus membranaceus 
on nephropathy as a complication of diabetes have also been shown [8]. The olive tree leaf (Olea europaea $L$.), which is one of the medicinal plants, is widely used in traditional medicine, especially in European and Mediterranean basin. It has been used in different ways as extracts, herbal teas and powders and, potentially contain bioactive compounds such as oleuropein, tocopherol, caffeic acid and luteolin [9]. Studies indicate that biologically active compounds in olive leaf products can exhibit a variety of biological actions, such as antioxidant [10], antimicrobial [11], anticancer [12], anti-hypertensive and vasodilator [13] properties. It has also been shown as possible diabetes-preventive components that decrease blood glucose concentrations, recover hyperglycemic symptoms, and enhance anti-oxidative activity [14]. Liu, Y.N. et al. [15] have demonstrated with an animal study that olive leaf extract (OLE) attenuate insulin resistance by suppressing mRNA expression of pro-inflammatory cytokines and elevating of IRS-1 expression. However, there is no in vitro cell culture study investigating the effects of OLE on both insulin receptors and carrier proteins with genotoxic, cytotoxic, and apoptotic effects. In this study, we aimed to investigate the effects of OLE on IRS-1, TK, GLUT-2, and GLUT-4 protein expression levels and, cytotoxic, genotoxic, apoptotic and reactive oxygen species (ROS) generating potentials.

\section{Materials and Methods}

\subsection{Chemicals}

The human hepatocellular carcinoma cells (HepG2) were purchased from ATCC (American Type Culture Collection, Manassas, VA 20110 USA). Fetal Bovine Serum (FBS), Penicillin-Streptomycin (10,000 U/mL), Trypsin-EDTA (0.25\%) with phenol red and E'MEM-Eagle Minimum Essential Media were purchased from Gibco (CA, USA). IRS-1, TK, GLUT-2, and GLUT-4 primer antibodies were provided by Santa Cruz Biotechnologies (Santa Cruz, California, USA), and ATP-Glo cell viability assay kit was provided by Promega (Madison, Wisconsin, USA). Other chemicals such as 2,7'-Dichlorodihydrofluorescein-diacetate (H2DCF-DA), ethidium bromide (EB), acridine orange (AO), ninhydrin, acetic acid, aluminum chloride $\left(\mathrm{AlCl}_{3}\right)$, cadmium chloride hemi (pentahydrate), $(+)$ quercetin, methanol, sodium hydroxide $(\mathrm{NaOH})$, gallic acid, L-Leucine, 2,4,6-tripyridyl-S-triazine (TPTZ), sodium nitrite $\left(\mathrm{NaNO}_{2}\right)$, potassium persulphate $\left(\mathrm{K}_{2} \mathrm{SO}_{4}\right)$, ferric chloride $\left(\mathrm{FeCl}_{3}\right)$, sodium chloride $(\mathrm{NaCl})$, sodium carbonate $\left(\mathrm{Na}_{2} \mathrm{CO}_{3}\right)$, ammonium ferrous sulphate, phosphoric acid $\left(\mathrm{H}_{3} \mathrm{PO}_{4}\right)$, Coomassie Brilliant Blue, 2,2'-azinobis-(3-ethylbenzothiazoline-6-sulfonate) (ABTS) and Oleuropein (purity $98 \%$ by HPLC) were purchased from Sigma-Aldrich Chemie GmbH (Steinheim, Germany). HPLC grade acetonitrile, methanol, ethyl acetate, and orthophosphoric acid were purchased from Merck Chemical (Darmstadt, Germany).

\subsection{Preparation of Olive Leaf Extract}

The fresh olive leaves (Olea europaea L.) were collected after fruit harvesting 
during December 2017 from an olive tree located in Tekirdag, Turkey. Extraction of olive leaf was prepared according to the method of Zahkok et al. [16] with slight modifications. Thus, $500 \mathrm{~g}$ of fresh olive leaf was washed, dried at $30^{\circ} \mathrm{C}$ for 5 days and crushed to a moderately-coarse powder. The fourth gram of resulting powder was divided into four equal parts and suspended in ethanol, methanol, acetonitrile, dichloromethane (70\%) for 24 hours. The supernatant was filtered, and solvents were evaporated at $45^{\circ} \mathrm{C}$ using rotary evaporator (Heidolph, Germany). Then, solvent-free extracts were dried by using a freeze drier system (Labconco; Kansas City, USA). The dry extracts obtained were kept away from the light (at room temperature) in amber-colored glass bottles until further analysis. The amount of OLE was expressed as milligram per gram of OLE. The OLE was dissolved in DMSO (0.1\%) and filtered with a Millipore membrane filter $(0.45 \mu \mathrm{m})$ prior to analysis.

\subsection{Determination of Total Flavonoids and Phenolic Contents}

The Folin-Ciocalteu method [17] was used to determine the total phenolic content of OLE. Fifty $\mu \mathrm{L}$ of filtered sample and $250 \mu \mathrm{L}$ of $0.2 \mathrm{~N}$ Folin-Ciocalteu reagent was mixed with vortex and kept $5 \mathrm{~min}$ at room temperature. Then it was mixed with $200 \mu \mathrm{L}$ of $0.7 \mathrm{~mol} \cdot \mathrm{L}^{-1} \mathrm{Na}_{2} \mathrm{CO}_{3}$. After incubation at room temperature for 2 hours, the absorbance of the reaction mixture was measured at $760 \mathrm{~nm}$ against a blank using a spectrophotometer (Varioskan Flash Multimode Reader, Thermo Scientific, USA). Gallic acid $\left(0-300 \mathrm{mg} \cdot \mathrm{L}^{-1}\right)$ was used as a standard to produce the calibration curve. The mean of three readings was used, and the total phenolic content was expressed in $\mathrm{mg}$ of gallic acid equivalents (GAE)/100 g OLE.

The total flavonoid content of the OLE samples was determined according to the colorimetric assay method developed by Zhishen et al. [18]. Fifty $\mu \mathrm{L}$ of filtered OLE samples were mixed with $250 \mu \mathrm{L}$ of distilled water and $15 \mu \mathrm{L}$ of a $5 \%$ $\mathrm{NaNO}_{2}$ solution. After $6 \mathrm{~min}, 30 \mu \mathrm{L}$ of $10 \% \mathrm{AlCl}_{3}$ solution was added, then 100 $\mu \mathrm{L} 1 \mathrm{~mol} \cdot \mathrm{L}^{-1} \mathrm{NaOH}$ was added, and the solution was incubated for a further 5 min at room temperature. The reaction mixture was mixed well, and the intensity of the red flavonoid-aluminum complex was measured at $510 \mathrm{~nm}$ using a spectrophotometer (Varioskan Flash Multimode Reader, Thermo Scientific, USA). A standard curve of quercetin was drawn within a concentration range of 5 to $50 \mathrm{mg} / \mathrm{L}$. Total flavonoid content was expressed as $\mathrm{mg}$ of quercetin equivalents per $100 \mathrm{~g}$ of OLE.

\subsection{Total Antioxidant Capacity Measurement}

The total antioxidant capacity (TAC) was determined according to the photometric method developed by Erel [19]. Briefly, $5 \mu \mathrm{L}$ of OLE samples were added to $500 \mu \mathrm{L}$ of $\mathrm{ABTS}^{+}$reagent and incubated at room temperature for 90 seconds. The color inhibition of the $\mathrm{ABTS}^{+}$radical was measured at $734 \mathrm{~nm}$ using a spectrophotometer (Varioskan Flash Multimode Reader, Thermo Scientific, USA). 
Results were expressed in mmol Trolox equivalents per $100 \mathrm{~g}$ of OLE.

\subsection{HPLC Analysis of Oleuropein}

Oleuropein concentration from OLE was determined according to the method of Al-Rimawi, F. [20]. The HPLC system (Thermo Fisher Dionex Ultimate 3000 UHPLC, USA) consisted of a quaternary gradient pump, UV-vis detector, and a reversed-phase C18 column $(250 \times 4.6 \mathrm{~mm}$ particle size $5 \mu \mathrm{m}$, Betasil-Thermo Scientific, USA) were used. Phosphate buffer $(0.05 \mathrm{~mol} / \mathrm{L}$ and $\mathrm{pH} 3$ adjusted with orthophosphoric acid) and acetonitrile (70:30, v/v) were used as mobile phase. Injection volume was $5 \mu \mathrm{L}$ for both standard and sample solution, flow rate was $1 \mathrm{~mL} / \mathrm{min}$, and column heat was adjusted to $24^{\circ} \mathrm{C}$. UV detector at 240 $\mathrm{nm}$ was used for oleuropein determination. Identification of oleuropein was based on retention times in comparison with standard of oleuropein. The concentration of oleuropein in the extracts was calculated using peak area. Oleuropein was dissolved in $100 \%$ methanol to prepare a stock standard at a concentration of $4000 \mathrm{mg} / \mathrm{L}$. Then, deionized water was used to dilute this and obtain standard solutions with concentrations between 100 and $800 \mathrm{mg} / \mathrm{L}$. Figure 1 shows chromatogram and calibration curve for oleuropein standard.

\subsection{Cell Viability Assay}

Cell Titer-Glo ${ }^{\circledast}$ Luminescent Cell Viability Test Kit (Promega, Madison, WI, USA) was used to measure cell viability level. This method determines the degree of cell viability in proportion to the amount of ATP. For analysis, HepG2 cancer cells $\left(1.5 \times 10^{3}\right.$ cells.well $\left.{ }^{-1}\right)$ were plated on 96-well plates. After 24 hours, the cells were incubated with different concentrations of Olive leave extract (2.5 to $320 \mu \mathrm{g} / \mathrm{mL}$ ). After incubation, the luciferin derivative and cell lysis solution were added as substrates. The luciferin derivative converts a light signal proportional to the current amount of ATP. Luminescence was measured using a Varioskan Flash Multimode Reader (Thermo Scientific, USA) and normalized to control.

\subsection{Intracellular Reactive Oxygen Species Measurement}

The intracellular reactive oxygen species (ROS) production levels were measured by the fluorometric method using a prob, $\mathrm{H}_{2}$ DCF-DA. $1.5 \times 10^{5}$ cells/well were seeded in each well of 96 wells. After 24 hours, they were treated with OLE at different concentrations ( 2.5 to $320 \mu \mathrm{g} / \mathrm{mL}$ ) and incubated for another 24 hours. The cells were washed with PBS and incubated with $5 \mu \mathrm{M} \mathrm{H}_{2}$ DCF-DA for 30 min at $37^{\circ} \mathrm{C}$ in the dark. The cells were then washed, resuspended in PBS, and measured for the ROS contents using a fluorimeter (Varioskan Flash Multimode Reader, Thermo Scientific, USA) and normalized to control.

\subsection{Genotoxicity Analysis}

Alkaline single cell gel electrophoresis assay (Comet Assay) was carried out with a slight modification of Singh et al. [19] to assess the genotoxic effects of olive 


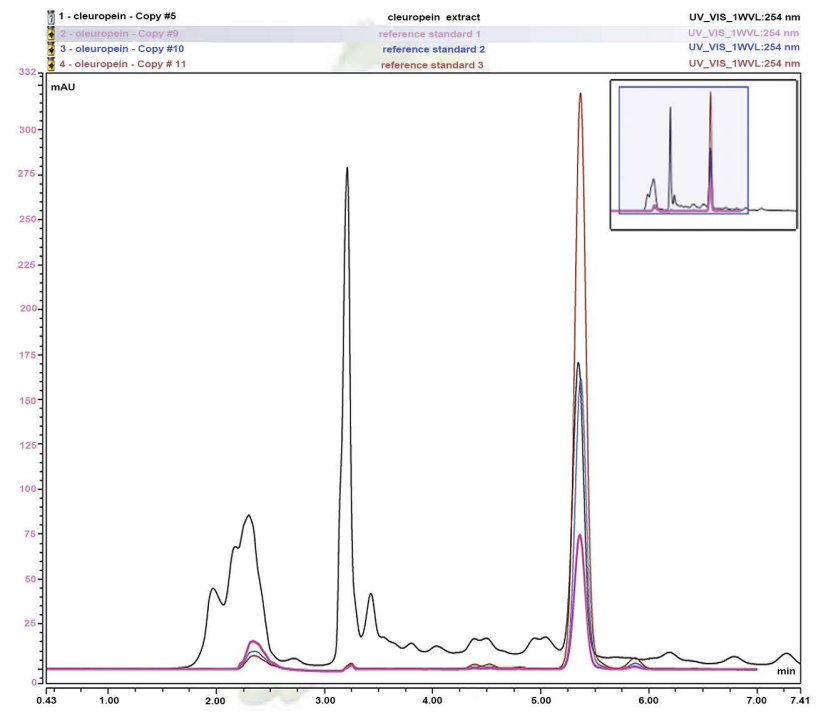

(a)

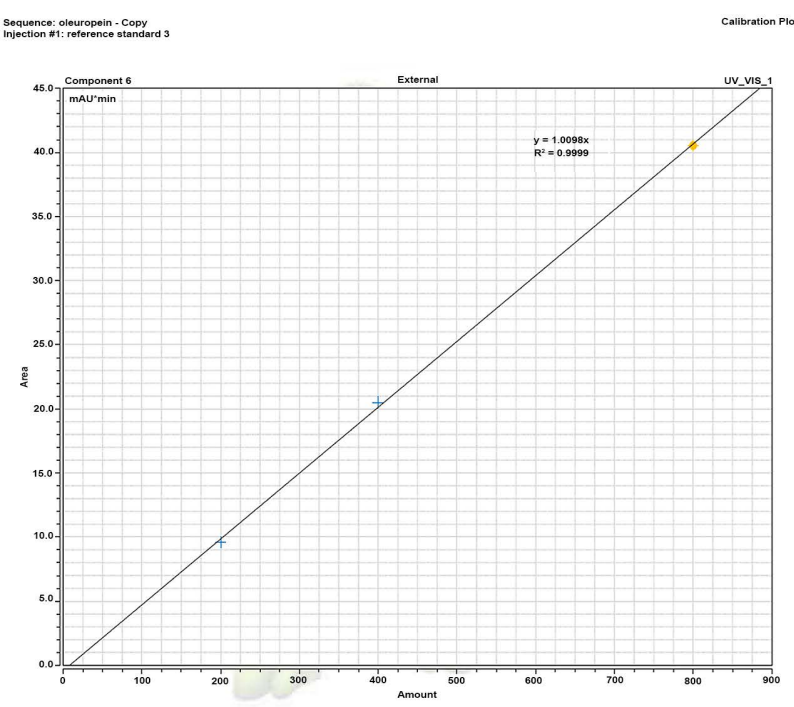

(b)

Figure 1. Chromatogram (a) and calibration curve (b) of oleuropein analyzed.

leaf extract on HepG2 cells. The cells were plated on 6-well cell culture plates (approximately $2 \times 10^{5}$ cells per well) containing cell culture medium and incubated at $37^{\circ} \mathrm{C}$. Then, the OLE samples below $\mathrm{IC}_{50}$ concentrations were added and incubated for another 24 hours. The cells were collected using trypsin/EDTA for $4 \mathrm{~min}$ at $4^{\circ} \mathrm{C}$ and centrifuged at $400 \times \mathrm{g}$ for $5 \mathrm{~min}$ at $4^{\circ} \mathrm{C}$. The supernatant was drained, and the cell density was adjusted to $2 \times 10^{5}$ cells $/ \mathrm{mL}$ using cold PBS. Ninety $\mu \mathrm{l}$ of $0.6 \%$ low melting point agarose (LMPA) and $10 \mu \mathrm{L}$ cell suspension were mixed and placed on $1 \%$ normal melting point agarose (NMPA) pre-coated slides. They were allowed to solidify on a cold tray for a few min, and the slides were then placed in lysis buffer, $\mathrm{pH} 10$ (1\% Triton X-100, $2.5 \mathrm{M} \mathrm{NaCl}, 10$ $\mathrm{mmol} \cdot \mathrm{L}^{-1}$ Tris, $0.1 \mathrm{~mol} \cdot \mathrm{L}^{-1}$ EDTA, Sigma-Aldrich) for 1 hour on the ice in the dark conditions. The slides were then incubated in an alkaline solution $(0.3$ $\mathrm{mol} \cdot \mathrm{L}^{-1} \mathrm{NaOH}, 1 \mathrm{mmol} \cdot \mathrm{L}^{-1}$ EDTA, Sigma-Aldrich) for $40 \mathrm{~min}$ at dark conditions in the presence of cooling blocks to unwind the DNA. Electrophoresis was performed at $0.72 \mathrm{~V} / \mathrm{cm}(26 \mathrm{~V}, 300 \mathrm{~mA})$ for $25 \mathrm{~min}$ in an electrophoresis tank at $4^{\circ} \mathrm{C}$. The slides were neutralized in Tris buffer (0.4 M Tris, $\mathrm{pH}$ : 7.5) for $5 \mathrm{~min}$ and then dehydrated with ethanol before staining. The slides were then stained with ethidium bromide (EB) $\left(2 \mu \mathrm{g} / \mathrm{mL}\right.$ in distilled $\left.\mathrm{H}_{2} \mathrm{O}, 70 \mu \mathrm{L} / \mathrm{slide}\right)$ coated with a coverslip and scored with a fluorescence microscope (Leica DM 1000, Solms, Germany) using the Comet assay IV software (Perceptive Instruments, Suffolk, $\mathrm{UK})$.

\subsection{Apoptosis Measurement}

Acridine orange/ethidium bromide (AO/EB), double staining test, was developed by Kaibhatla et al. [21] Apoptotic cells are separated from living cells by morphological changes in the nuclei. While $\mathrm{AO}$ is taken by both living and dead cells, EB stains only apoptotic cell nucleus [22]. AO spreads green fluorescence 
at $480-490 \mathrm{~nm}$ from living cells while spreading to dsDNA. Briefly, $2 \times 10^{5}$ cells/well were seeded in 6 well-plate and incubated for 24 hours. Then, the olive leaf samples below $\mathrm{IC}_{50}$ concentrations were added and incubated for another 24 hours. Following OLE treatment, the cells were collected and washed with PBS, followed by staining with 1:1 mixture of $\mathrm{AO} / \mathrm{EB}(100 \mu \mathrm{g} / \mathrm{mL})$. Triplicate samples of 100 cells each were counted and scored for the incidence of apoptotic chromatin condensation using a fluorescent microscope (Leica DM 1000, Solms, Germany).

\subsection{Immunoblotting Measurements}

HepG2 cells were seeded on six-well plates at $1.5 \times 10^{5}$ cells per well and incubated for 24 hours. It was then treated with olive leaf extract according to their $\mathrm{IC}_{50}$ values. After 24 hours of incubation, the cells were harvested and prepared in NP-40 cell lysis buffer $\left(2 \mathrm{mmol} \cdot \mathrm{L}^{-1}\right.$ Tris- $\mathrm{HCl} \mathrm{pH} 7.5,150 \mathrm{mmol} \cdot \mathrm{L}^{-1} \mathrm{NaCl}, 10 \%$ glycerol and $0.2 \% \mathrm{NP}-40$ plus a protease inhibitor cocktail) for $30 \mathrm{~min}$ on ice and centrifuged at 14,000 $\times \mathrm{g}$ (Beckman Coulter, Krefeld, Germany) for $10 \mathrm{~min}$ at $4^{\circ} \mathrm{C}$. The final supernatant was then used as the cytosolic fraction. The protein concentration of the supernatant was determined using the Bradford protein assay method [23]. Proteins from cellular supernatants were separated on $8 \%$ to $10 \%$ polyacrylamide gel and transferred to a nitrocellulose membrane using the Trans-blot SD semi-permeable electrophoretic transfer cell (Bio-Rad, Hercules, CA, USA). Tris-HCl buffered saline with Tween 20 (TBST) with 5\% non-fat-milk was used for blocking the membrane. The primary antibodies, IRS-1, TK, GLUT-2, and GLUT-4 (1/500 dilution) were used after a night incubation $\left(4^{\circ} \mathrm{C}\right)$. All samples were also blotted for $\beta$-actin to normalize protein amounts. TBST were used for washing the membrane and incubated with horseradish peroxidase-conjugated secondary antibodies (Cell Signaling Technology) for another 1 hour. Immunolabelled proteins were visualized using ECL Western staining substrate (Thermo Scientific) and captured with an imaging system (Vilber Lourmat Sté, Collégien, France).

\subsection{Statistical Analysis}

The experiments were repeated 3 times, and the results were expressed as mean value \pm standard deviation (Mean \pm SD). Statistical evaluation was performed using the analysis of variance (One-way ANOVA). Differences with a probability value of $p<0.05$ were accepted statistically significant. $\mathrm{IC}_{50}$ values of OLE over the cell line were calculated by nonlinear regression analysis. The statistical analysis was performed by using Statistical Package for Social Sciences (SPSS) version 21.

\section{Results}

\subsection{Total Phenol, Flavonoids, Antioxidant and Oleuropein Contents of Olive Leaf Extracts}

Total phenol, flavonoid, antioxidant and OLE contents of four different ex- 
tracted samples were different and, the highest total phenol, flavonoid, antioxidant, and OLE contents were found in the samples extracted with methanol (Figure 2).

\subsection{Cell Culture Studies}

\subsubsection{Cell Viability Assessment of Olive Leaf Extract}

To assess the effect of OLE on cell growth, HepG2 cells were treated with different concentrations of OLE ( 2.5 to $320 \mu \mathrm{g} / \mathrm{mL}$ ) for 24 hours. After incubation, the cytotoxic effect of OLE was measured by ATP cell viability test. The cell viability of the control cells was $100 \%$. Cell viability was increased to $120 \%$ at a concentration of $10 \mu \mathrm{g} / \mathrm{mL}$ compared to the control after 24 hours of addition of the OLE. At doses above this concentration, cytotoxic activity increased in a concentration-dependent manner $(p<0.001)$. The 50\% inhibitory concentration (IC50) was found $88 \mu \mathrm{g} / \mathrm{mL}$ (Figure 3 ). These findings demonstrated that OLE has a proliferative effect at lower concentrations, but it shows cell dead effect at higher concentrations.

\subsubsection{Reactive 0xygen Species Generation Assessment}

We measured intracellular ROS formation by the fluorometric method using the $\mathrm{H}_{2}$ DCF-DA probe. Low OLE dose $(10 \mu \mathrm{g} / \mathrm{mL})$ significantly reduced ROS production in HepG2 cells $(p<0.05)$. ROS levels were significantly increased when the dose of OLE was over $40 \mu \mathrm{g} / \mathrm{mL}$ (Figure 3).

\subsubsection{Genotoxic Assessment of Olive Leaf Extract}

For DNA damage analysis, HepG2 cells were treated with different doses of OLE
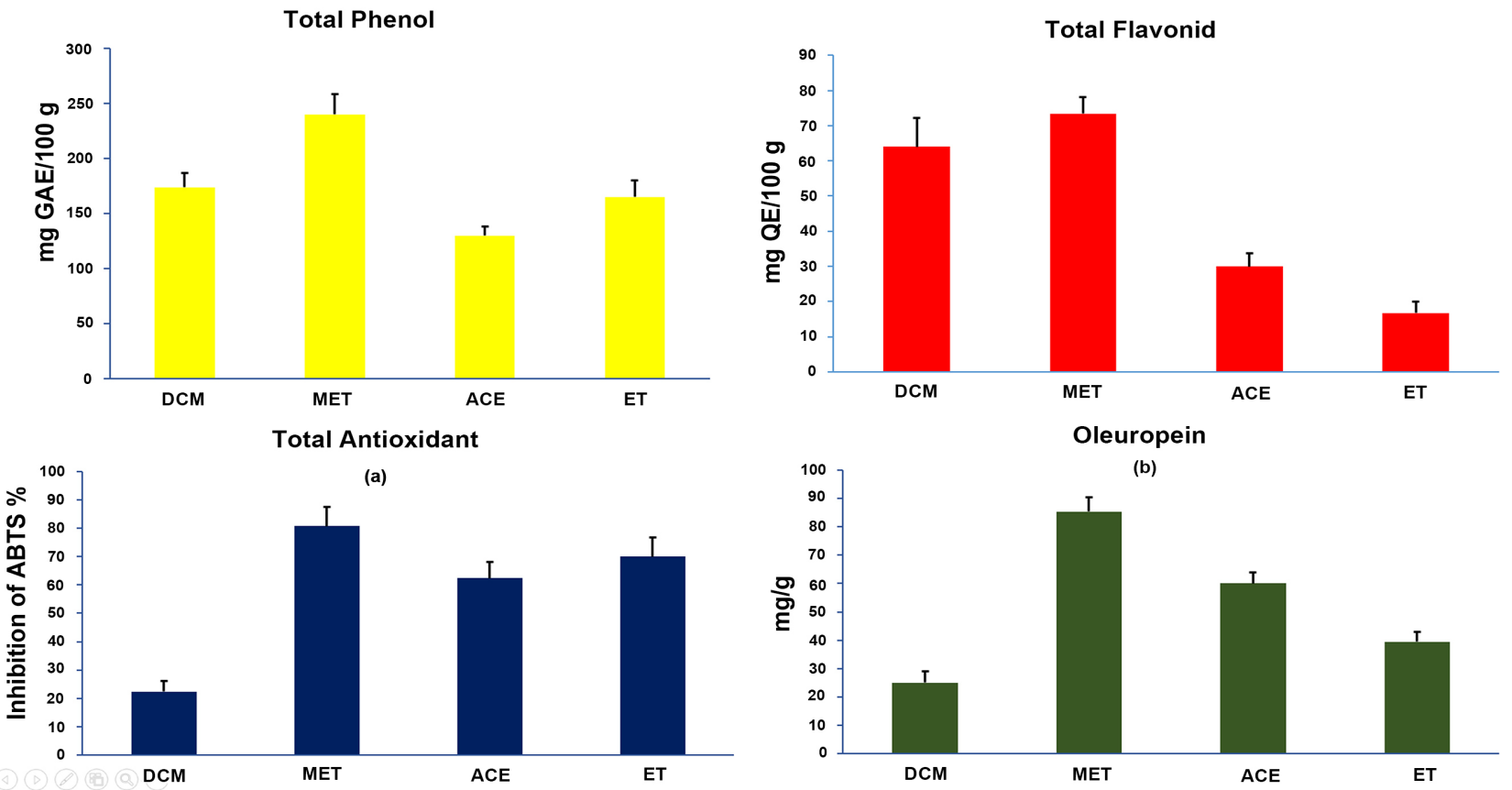

(b)

(c)

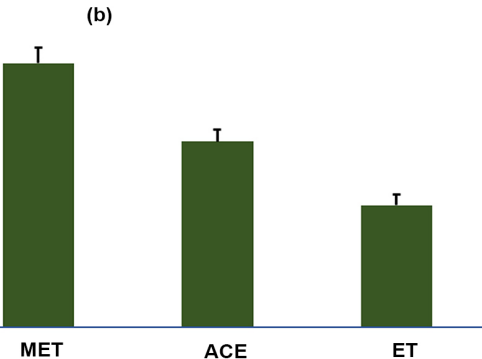

(d)

Figure 2. Total phenol (a), flavonoid (b), antioxidant capacity (c) and oleuropein content (d) of olive leaf extract samples obtained by using four different solvents (dichloromethane (DCM), Methanol (MET), acetonitrile (ACE), ethanol (ET). 

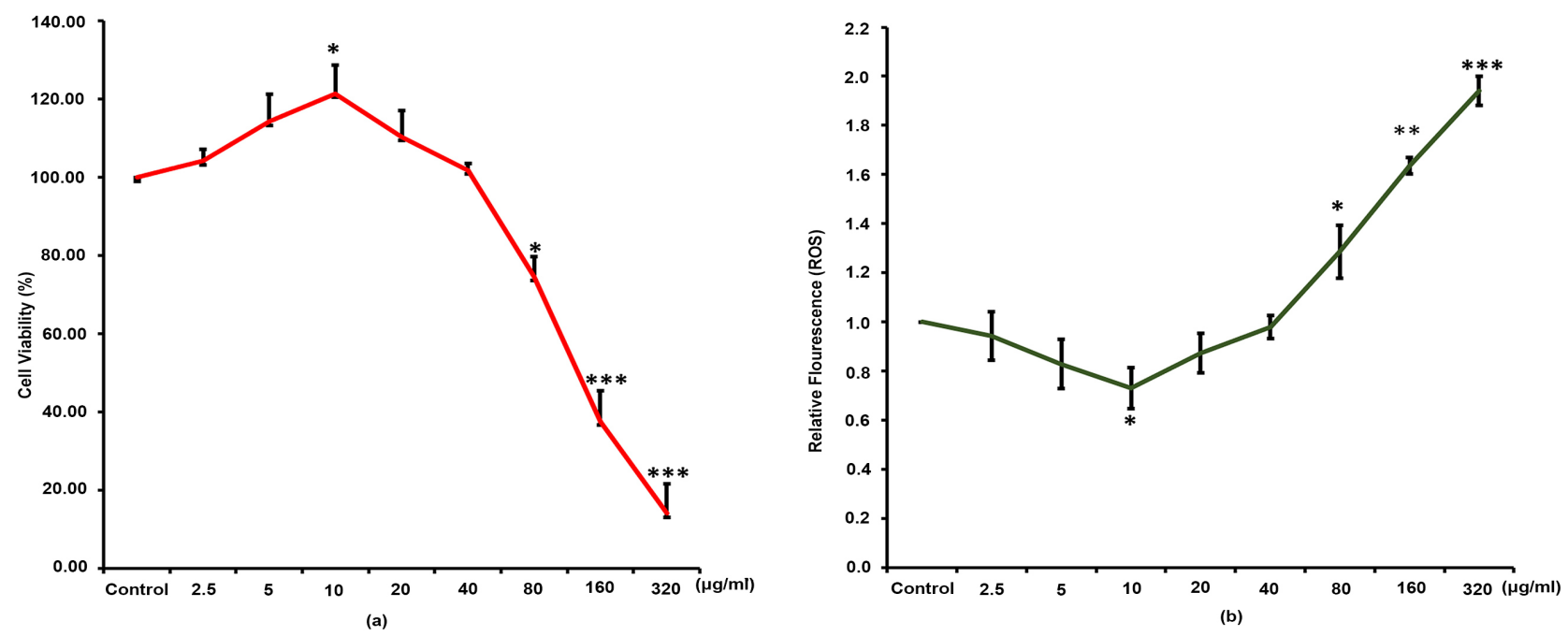

Figure 3. HepG2 cells were treated with 2.5, 5, 10, 20, 40, 80160 and $320 \mu \mathrm{g} / \mathrm{mL}$ olive leaf extract and incubated for 24 hours. (a) cell viability assay was performed to determine cytotoxicity. The percentage of cell viability was calculated as a control of $100 \%$; (b) Reactive oxygen generating assay was performed to determine pro-oxidant activity of Olive leaf extract. Significant differences compared to the control are indicated by ${ }^{\star} p<0.05$ and ${ }^{* *} p<0.01$.

samples (2.5 to $160 \mu \mathrm{g} / \mathrm{mL}$ ) for 24 hours, and the DNA damage was measured via the Comet Assay method. Damaged DNA appears in a bright head and comet, while undamaged DNA appears to be only round. After 24 hours incubation, the $\%$ tail intensity did not increase up to $80 \mu \mathrm{g} / \mathrm{mL}$ doses. It increased significantly with the increasing doses over $80 \mu \mathrm{g} / \mathrm{mL}$ (Figure 4).

\subsubsection{Acridine Orange/Ethidium Bromide Double Staining}

Apoptosis is important in determining tumor formation and resistance to treatment. In our study, we performed AO/EB double staining to evaluate the apoptotic effects of different concentrations of OLE in cancer cells. HepG2 cells were incubated with OLE for 24 hours to demonstrate the morphological characteristics of apoptosis on cells. It was then stained with $\mathrm{AO} / \mathrm{EB}$ double staining and examined under fluorescence microscopy. After 24 hours of incubation, as the administered dose increased, the green-looking viable cell ratios decreased, and the yellow-orange-looking apoptotic cell ratios increased. Apoptotic cells increased significantly after $40 \mathrm{mg} / \mathrm{mL}$ doses, while necrotic cell ratios increased after $100 \mu \mathrm{g} / \mathrm{mL}$ (Figure 4).

\subsubsection{Western Blotting Results}

In order to investigate the relationship between the olive leaf extract, insulin receptors and transfer proteins, the expression levels of IRS-1, TK, GLUT-2, and GLUT- 4 were analyzed by western blotting method. For this purpose, HepG2 cells were treated with OLE at different concentrations for 24 hours. Cell extracts were used for western blotting. The $\beta$-actin was used as a control. The results showed that both insulin receptors and transport protein expression levels increased up to $10 \mu \mathrm{g} / \mathrm{mL}$. All protein expression levels increased approximately fivefold according to the control. Their levels decreased significantly with increasing doses after $10 \mu \mathrm{g} / \mathrm{mL}$ (Figure 5). 

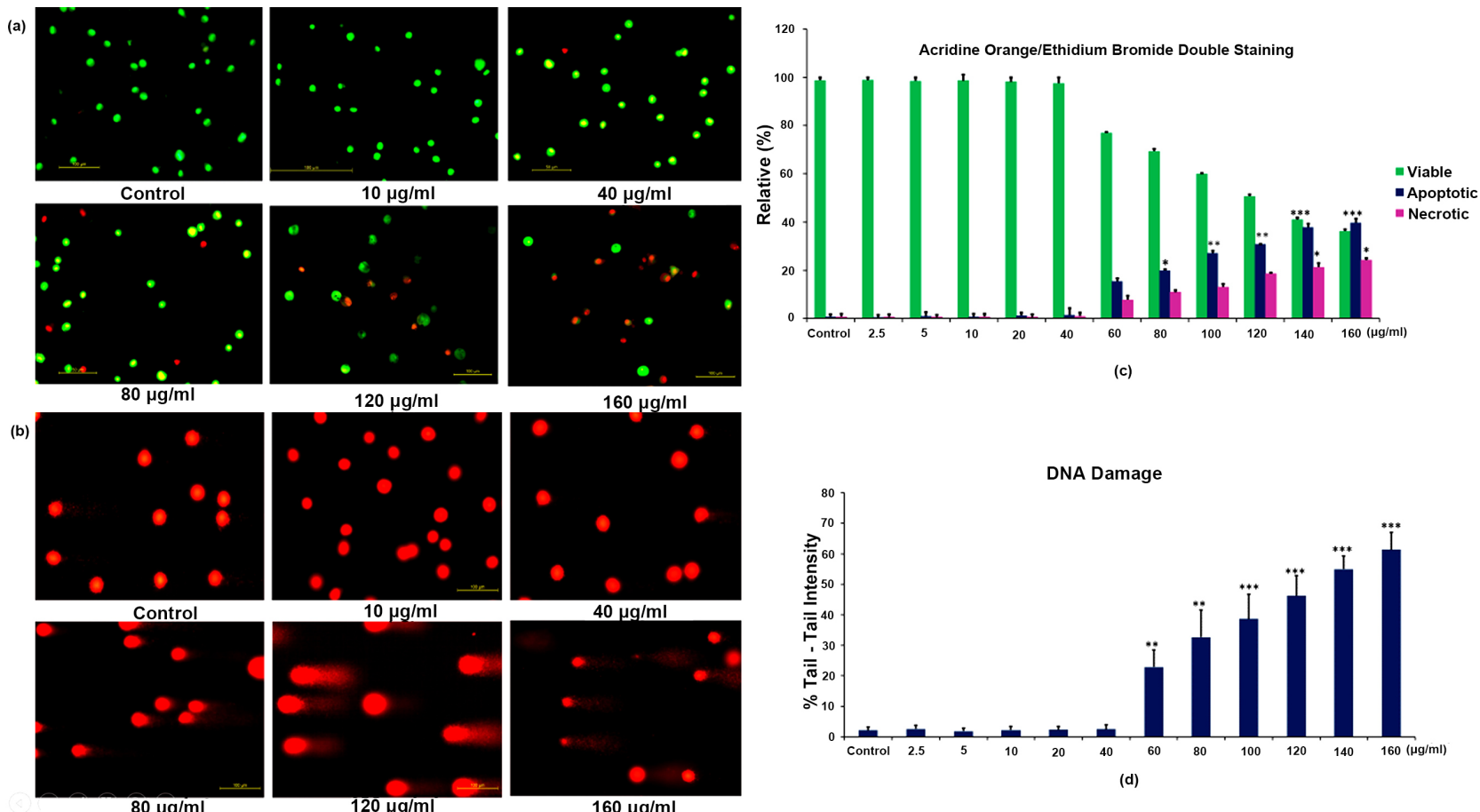

Figure 4. HepG2 cells were treated with different concentrations of OLE (2.5 to $160 \mu \mathrm{g} / \mathrm{mL})$ for 24 hours, the genotoxic effect was analyzed with comet assay method (a) and apoptotic activity was analyzed with acridine orange/ethidium bromide double staining methods (b). There were significant changes in the tail \% of DNA according to the control with the increasing concentrations (c), Increased percentage of apoptotic cells according to the control with the increasing concentrations of extract (d) Significant differences indicated by ${ }^{*} p<0.05,{ }^{* *} p<0.01$ and ${ }^{* *} p<0.001$.

\section{Discussion}

Olive tree leaves have been widely used in traditional medicine in European and Mediterranean countries, and antidiabetic effects of OLE have been shown in several studies [14] [24] [25]. The bioactivity of olive leaf extracts appears to be due to the antioxidant and phenolic compounds such as oleuropein, hydroxytyrosis, oleuropein aglycone, and tyrosol [25]. Specifically, oleuropein has been reported to have an anti-hyperglycemic effect in diabetic rats [26]. However, the molecular mechanism of OLE to alleviate hyperglycemia remains unclear.

Two possible mechanisms of hypoglycemic effect of OLE are 1) enhanced glucose-induced insulin secretion, and 2) increased peripheral glucose uptake [9]. Insulin requires insulin receptors and transfer proteins to increase glucose uptake in peripheral tissues [27]. Binding of insulin to its receptor activates the phosphorylation of insulin receptor TK and the family of insulin receptor substrates (IRS), especially IRS-1 and IRS-2 [28]. The phosphorylated IRS proteins bind to intracellular signal molecules, phosphatidylinositol 3 kinase (PI3K) and serine/threonine kinase PI3K-linked protein kinase B (Akt/PKB) and, activate them. The activation of Akt/PKB stimulates GLUT-4, which results in enhanced glucose uptake [29]. Previous studies have shown that insulin resistance is most likely due to a defect in the insulin receptor IRS 1/PI3K cascade [30]. The present study demonstrated that OLE increased expressions of insulin receptors 


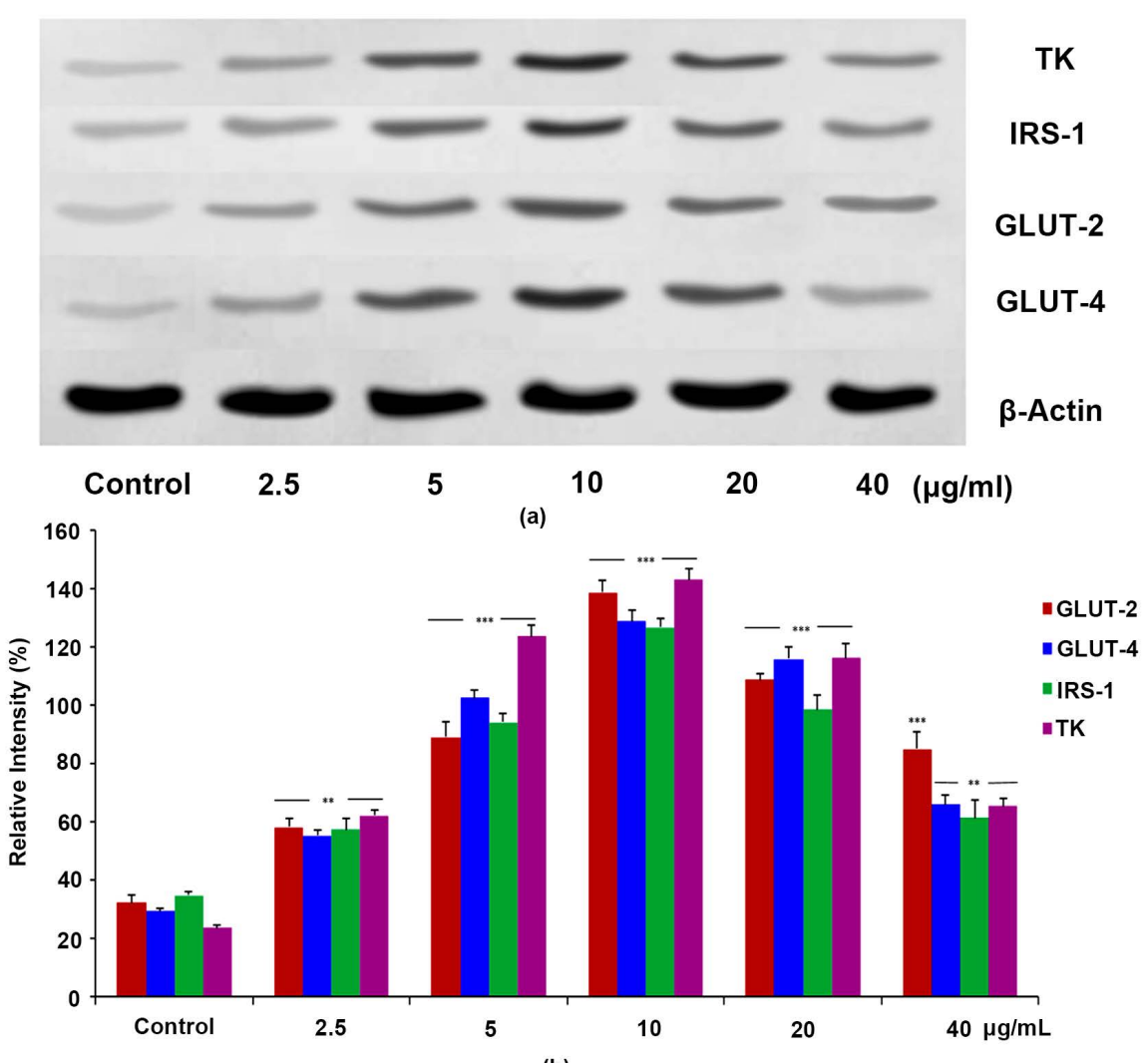

(b)

Figure 5. (a) Western blot analyses were performed to determine IRS-1, TK, GLUT-2, and GLUT-4 protein expression levels. HepG2 cells were treated with different doses of OLE (2.5 to $40 \mu \mathrm{g} / \mathrm{mL}$ ) for 24 hours. (b) Changes in the protein levels were given in $\%$ according to the control. Significant differences according to the control indicated by ${ }^{\star} p<$ $0.05,{ }^{* *} p<0.01,{ }^{* *} p<0.001$.

IRS- 1 and TK at the optimum dose $(10 \mu \mathrm{g} / \mathrm{mL})$ in HepG2 cells. The present study also demonstrated that OLE upregulated the expression transport proteins GLUT-2 and GLUT-4 at optimum dose. However, the expression levels of these proteins decreased under and above this optimal dose. To the best of our knowledge, this is the first in vitro study to show that OLE increases insulin expression pathways with direct effect insulin signaling pathways. In addition, the present findings have shown that it is important to determine the dose at which insulin signal receptors and transfer proteins are expressed at the maximum levels.

In fact, OLE is known for its antioxidant, antihypertensive, anti-atherogenic, anti-inflammatory, anticancer, hypoglycemic, and hypocholesterolemia properties [31] [32]. OLE is also known for its anti-genotoxic properties. The protective effects of OLE by decreasing the level of oxidative stress-induced DNA damage in peripheral blood cells have been previously demonstrated [33] [34]. In fact, OLE has been recently accepted as a safe product in the category of food additives, approved by the European Food Safety Authority (EFSA) [35]. However, OLE has recently been shown to have cytotoxic, genotoxic, and apoptotic action in an in vitro cell culture medium, depending on dose and time [36] [37] [38]. 
Therefore, we researched genotoxic, apoptotic, cytotoxic, and ROS generating effects of different concentrations of OLE on HepG2 cells. In our study, we demonstrated that OLE proliferates to $120 \%$ at a concentration of $10 \mu \mathrm{g} / \mathrm{mL}$, then it has an anti-proliferative effect in a dose-dependent manner. ROS production also decreased significantly at concentrations of $10 \mu \mathrm{g} / \mathrm{mL}$ and increased with dose increase.

Similarly, we observed that DNA damage and apoptosis increased significantly at doses above $80 \mu \mathrm{g} / \mathrm{mL}$. These results showed that OLE has a proliferative effect with its antioxidant activity at low doses, whereas it has anti-proliferative, genotoxic, and apoptotic effect with its pro-oxidant activity at higher doses. It has previously been found that high concentrations of phenolic compounds found in olive products show genotoxic and pro-oxidant effects [39]. It was demonstrated that their pro-oxidant or antioxidant activity depends on the concentration and duration of exposure [40]. Cabarkapa et al. [38] claimed that olive leaves increased DNA damage and this damage was due to pro-oxidant rather than antioxidant effect. Vizza et al. [41] also demonstrated that in HeLa cells OLE exerts pro-apoptotic effects. Studies have shown that OLE contains much more antioxidant activity composition than the fruit, and oleuropein, flavonoids such polyphenols are the main active ingredients in olive leaf [42]. Normally, antioxidants inhibit oxidative damage as a consequence of their ability to inhibit ROS but exhibit pro-oxidant activity at high doses in the presence of transition metals such as iron (III) and copper (II) [43]. According to our knowledge, this study is the first in vitro study showing both antioxidant and pro-oxidant effects of OLE, and the results of previous studies support our findings.

\section{Conclusion}

Olive leaf extract may have the potential to treat T2DM as it increases expression levels of IRS-1, TK and glucose transport proteins. However, it is very important to determine the optimum and safe dose of OLE to obtain the best results. Therefore, experimental animal and clinical researches are required to find the most effective and non-toxic therapeutic concentrations.

\section{Limitation}

Our limitation for this study: the effects of high and basal glucose conditions on IRS-1, TK and GLUT protein expressions were not investigated.

\section{Funding}

This work was funded by the Bezmialem Vakif University Scientific Research Projects Unit (No: 6.2016/57).

\section{Conflicts of Interest}

The authors declare that there are no conflicts of interest. 


\section{References}

[1] DeFronzo, R.A., Ferrannini, E., Groop, L., Henry, R.R., Herman, W.H., Holst, J.J., Hu, F.B., Kahn, C.R., Raz, I. and Shulman, G.I. (2015) Type 2 Diabetes Mellitus. Nature Reviews Disease Primers, 1, 15019. https://doi.org/10.1038/nrdp.2015.19

[2] Candar, A., Demirci, H., Baran, A.K. and Akpınar, Y. (2018) The Association between Quality of Life and Complementary and Alternative Medicine Use in Patients with Diabetes Mellitus. Complementary Therapies in Clinical Practice, 31, 1-6. https://doi.org/10.1016/j.ctcp.2018.01.002

[3] Chatterjee, S., Khunti, K. and Davies, M.J. (2017) Type 2 Diabetes. The Lancet, 389, 2239-2251. https://doi.org/10.1016/S0140-6736(17)30058-2

[4] Jia, G., DeMarco, V.G. and Sowers, J.R. (2016) Insulin Resistance and Hyperinsulinaemia in Diabetic Cardiomyopathy. Nature Reviews Endocrinology, 12, 144. https://doi.org/10.1038/nrendo.2015.216

[5] Zierath, J., He, L., Guma, A., Wahlström, E.O., Klip, A. and Wallberg-Henriksson, H. (1996) Insulin Action on Glucose Transport and Plasma Membrane GLUT4 Content in Skeletal Muscle from Patients with NIDDM. Diabetologia, 39, 1180. https://doi.org/10.1007/BF02658504

[6] Samuel, V.T. and Shulman, G.I. (2016) The Pathogenesis of Insulin Resistance: Integrating Signaling Pathways and Substrate Flux. The Journal of Clinical Investigation, 126, 12-22. https://doi.org/10.1172/JCI77812

[7] Subash-Babu, P., Ignacimuthu, S. and Alshatwi, A. (2015) Nymphayol Increases Glucose-Stimulated Insulin Secretion by RIN-5F Cells and GLUT4-Mediated Insulin Sensitization in Type 2 Diabetic Rat Liver. Chemico-Biological Interactions, 226, 72-81. https://doi.org/10.1016/j.cbi.2014.12.011

[8] Li, M., Wang, W., Xue, J., Gu, Y. and Lin, S. (2011) Meta-Analysis of the Clinical Value of Astragalus membranaceus in Diabetic Nephropathy. Journal of Ethnopharmacology, 133, 412-419. https://doi.org/10.1016/j.jep.2010.10.012

[9] El, S.N. and Karakaya, S. (2009) Olive Tree (Olea europaea) Leaves: Potential Beneficial Effects on Human Health. Nutrition Reviews, 67, 632-638. https://doi.org/10.1111/j.1753-4887.2009.00248.x

[10] Le Tutour, B. and Guedon, D. (1992) Antioxidative Activities of Olea europaea Leaves and Related Phenolic Compounds. Phytochemistry, 31, 1173-1178. https://doi.org/10.1016/0031-9422(92)80255-D

[11] Pereira, A.P., Ferreira, I.C., Marcelino, F., Valentão, P., Andrade, P.B., Seabra, R., Estevinho, L., Bento, A. and Pereira, J.A. (2007) Phenolic Compounds and Antimicrobial Activity of Olive (Olea europaea L. CV. Cobrançosa) Leaves. Molecules, 12, 1153-1162. https://doi.org/10.3390/12051153

[12] De Marino, S., Festa, C., Zollo, F., Nini, A., Antenucci, L., Raimo, G. and Iorizzi, M. (2014) Antioxidant Activity and Chemical Components as Potential Anticancer Agents in the Olive Leaf (Olea europaea L. cv Leccino.) Decoction. Anti-Cancer Agents in Medicinal Chemistry, 14, 1376-1385. https://doi.org/10.2174/1871520614666140804153936

[13] Zarzuelo, A., Duarte, J., Jimenez, J., Gonzalez, M. and Utrilla, M. (1991) Vasodilator Effect of Olive Leaf. Planta Medica, 57, 417-419. https://doi.org/10.1055/s-2006-960138

[14] Wainstein, J., Ganz, T., Boaz, M., Bar Dayan, Y., Dolev, E., Kerem, Z. and Madar, Z. (2012) Olive Leaf Extract as a Hypoglycemic Agent in Both Human Diabetic Subjects and in Rats. Journal of Medicinal Food, 15, 605-610. https://doi.org/10.1089/jmf.2011.0243 
[15] Liu, Y.N., Jung, J.H., Park, H. and Kim, H. (2014) Olive Leaf Extract Suppresses Messenger RNA Expression of Proinflammatory Cytokines and Enhances Insulin Receptor Substrate 1 Expression in the Rats with Streptozotocin and High-Fat Diet-Induced Diabetes. Nutrition Research, 34, 450-457. https://doi.org/10.1016/j.nutres.2014.04.007

[16] Zahkok, S., Abo-Elnaga, N., Ismail, A.F. and Mousa, E. (2016) Studies on Fertility of Diabetic Male Rats Treated with Olive Leaves Extract. Journal of Biomedical and Pharmaceutical Research, 5.

[17] Singleton, V.L., Orthofer, R. and Lamuela-Raventós R.M. (1999) [14] Analysis of Total Phenols and Other Oxidation Substrates and Antioxidants by Means of Folin-Ciocalteu Reagent. Methods in Enzymology, 299, 152-178. https://doi.org/10.1016/S0076-6879(99)99017-1

[18] Jia, Z.S., Tang, M.C. and Wu, J.M. (1999) The Determination of Flavonoid Contents in Mulberry and Their Scavenging Effects on Superoxide Radicals. Food Chemistry, 64, 555-559. https://doi.org/10.1016/S0308-8146(98)00102-2

[19] Erel, O. (2004) A Novel Automated Direct Measurement Method for Total Antioxidant Capacity Using a New Generation, More Stable ABTS Radical Cation. Clinical Biochemistry, 37, 277-285. https://doi.org/10.1016/j.clinbiochem.2003.11.015

[20] Al-Rimawi, F. (2014) Development and Validation of a Simple Reversed-Phase HPLC-UV Method for Determination of Oleuropein in Olive Leaves. Journal of Food and Drug Analysis, 22, 285-289. https://doi.org/10.1016/j.jfda.2013.10.002

[21] Kasibhatla, S., Amarante-Mendes, G.P., Finucane, D., Brunner, T., Bossy-Wetzel, E. and Green, D.R. (2006) Acridine Orange/Ethidium Bromide (AO/EB) Staining to Detect Apoptosis, Cold Spring Harbor Protocols. https://doi.org/10.1101/pdb.prot4493

[22] Smith, S.M., Ribble, D., Goldstein, N.B., Norris, D.A. and Shellman, Y.G. (2012) A Simple Technique for Quantifying Apoptosis in 96-Well Plates. Methods in Cell Biology, 112, 361-368. https://doi.org/10.1016/B978-0-12-405914-6.00020-2

[23] Bradford, M.M. (1976) A Rapid and Sensitive Method for the Quantitation of Microgram Quantities of Protein Utilizing the Principle of Protein-Dye Binding. Analytical Biochemistry, 72, 248-254. https://doi.org/10.1006/abio.1976.9999

[24] Eidi, A., Eidi, M. and Darzi, R. (2009) Antidiabetic Effect of Olea europaea L. in Normal and Diabetic Rats. Phytotherapy Research: An International Journal Devoted to Pharmacological and Toxicological Evaluation of Natural Product Derivatives, 23, 347-350. https://doi.org/10.1002/ptr.2629

[25] Navarro, M. and Morales, F.J. (2017) Evaluation of an Olive Leaf Extract as a Natural Source of Antiglycative Compounds. Food Research International, 92, 56-63. https://doi.org/10.1016/j.foodres.2016.12.017

[26] Jemai, H., El Feki, A. and Sayadi, S. (2009) Antidiabetic and Antioxidant Effects of Hydroxytyrosol and Oleuropein from Olive Leaves in Alloxan-Diabetic Rats. Journal of Agricultural and Food Chemistry, 57, 8798-8804.

https://doi.org/10.1021/jf901280r

[27] Haeusler, R.A., McGraw, T.E. and Accili, D. (2018) Biochemical and Cellular Properties of Insulin Receptor Signaling. Nature Reviews Molecular Cell Biology, 19, 31-44. https://doi.org/10.1038/nrm.2017.89

[28] Krüger, M., Kratchmarova, I., Blagoev, B., Tseng, Y.-H., Kahn, C.R. and Mann, M. (2008) Dissection of the Insulin Signaling Pathway via Quantitative Phosphoproteomics. Proceedings of the National Academy of Sciences of the United States of America, 105, 2451-2456. https://doi.org/10.1073/pnas.0711713105 
[29] Hiratani, K., Haruta, T., Tani, A., Kawahara, J., Usui, I. and Kobayashi, M. (2005) Roles of mTOR and JNK in Serine Phosphorylation, Translocation, and Degradation of IRS-1. Biochemical and Biophysical Research Communications, 335, 836-842. https://doi.org/10.1016/j.bbrc.2005.07.152

[30] Broca, C., Breil, V., Cruciani-Guglielmacci, C., Manteghetti, M., Rouault, C., Derouet, M., Rizkalla, S., Pau, B., Petit, P. and Ribes, G. (2004) The Insulinotropic Agent ID1101 (4-Hydroxyisoleucine) Activates Insulin Signaling in Rat. American Journal of Physiology-Endocrinology and Metabolism, 87, E463-E471.

[31] Çoban, J., Öztezcan, S., Doğru-Abbasoğlu, S., Bingül, I., Yeşil-Mizrak, K. and Uysal, M. (2014) Olive Leaf Extract Decreases Age-Induced Oxidative Stress in Major Organs of Aged Rats. Geriatrics \& Gerontology International, 14, 996-1002. https://doi.org/10.1111/ggi.12192

[32] Talhaoui, N., Taamalli, A., Gómez-Caravaca, A.M., Fernández-Gutiérrez, A. and Segura-Carretero, A. (2015) Phenolic Compounds in Olive Leaves: Analytical Determination, Biotic and Abiotic Influence, and Health Benefits. Food Research International, 77, 92-108. https://doi.org/10.1016/j.foodres.2015.09.011

[33] Žukovec Topalović, D., Živković, L., Čabarkapa, A., Djelić, N., Bajić, V., Dekanski, D. and Spremo-Potparević, B. (2015) Dry Olive Leaf Extract Counteracts L-Thyroxine-Induced Genotoxicity in Human Peripheral Blood Leukocytes in $\mathrm{Vi}$ tro. Oxidative Medicine and Cellular Longevity, 2015, Article ID: 762192. https://doi.org/10.1155/2015/762192

[34] Čabarkapa, A., Živković, L., Žukovec, D., Djelić, N., Bajić, V., Dekanski, D. and Spremo-Potparević, B. (2014) Protective Effect of Dry Olive Leaf Extract in Adrenaline Induced DNA Damage Evaluated Using in Vitro Comet Assay with Human Peripheral Leukocytes. Toxicology in Vitro, 28, 451-456.

https://doi.org/10.1016/j.tiv.2013.12.014

[35] EFSA Panel on Dietetic Products, Nutrition and Allergies (NDA) (2014) Scientific Opinion on the Substantiation of a Health Claim Related to Olive (Olea europaea L.) Leaf Water Extract and Increase in Glucose Tolerance Pursuant to Article 13 (5) of Regulation (EC) No 1924/2006. EFSA Journal, 12, 3655. https://doi.org/10.2903/j.efsa.2014.3655

[36] Samet, I., Han, J., Jlaiel, L., Sayadi, S. and Isoda, H. (2014) Olive (Olea europaea) Leaf Extract Induces Apoptosis and Monocyte/Macrophage Differentiation in $\mathrm{Hu}$ man Chronic Myelogenous Leukemia K562 Cells: Insight into the Underlying Mechanism. Oxidative Medicine and Cellular Longevity, 2014, Article ID: 927619. https://doi.org/10.1155/2014/927619

[37] Anter, J., Fernández-Bedmar, Z., Villatoro-Pulido, M., Demyda-Peyras, S., Moreno-Millán, M., Alonso-Moraga, Á., Muñoz-Serrano, A. and de Castro, M.D.L. (2011) A Pilot Study on the DNA-Protective, Cytotoxic, and Apoptosis-Inducing Properties of Olive-Leaf Extracts. Mutation Research/Genetic Toxicology and Environmental Mutagenesis, 723, 165-170. https://doi.org/10.1016/j.mrgentox.2011.05.005

[38] Čabarkapa, A., Dekanski, D., Živković, L., Milanović-Čabarkapa, M., Bajić, V., Topalović, D., Giampieri, F., Gasparrini, M., Battino, M. and Spremo-Potparević, B. (2017) Unexpected Effect of Dry Olive Leaf Extract on the Level of DNA Damage in Lymphocytes of Lead Intoxicated Workers, before and after CaNa2EDTA Chelation Therapy. Food and Chemical Toxicology, 106, 616-623.

https://doi.org/10.1016/j.fct.2016.12.023

[39] Nousis, L., Doulias, P.-T., Aligiannis, N., Bazios, D., Agalias, A., Galaris, D. and Mitakou, S. (2005) DNA Protecting and Genotoxic Effects of Olive Oil Related Com- 
ponents in Cells Exposed to Hydrogen Peroxide. Free Radical Research, 39, 787-795. https://doi.org/10.1080/10715760500045806

[40] Procházková, D., Boušová, I. and Wilhelmová, N. (2011) Antioxidant and Prooxidant Properties of Flavonoids. Fitoterapia, 82, 513-523.

https://doi.org/10.1016/j.fitote.2011.01.018

[41] Vizza, D., Lupinacci, S., Toteda, G., Puoci, F., Ortensia, I.P., De Bartolo, A., Lofaro, D., Scrivano, L., Bonofiglio, R., La Russa, A., Bonofiglio, M. and Perri, A. (2019) An Olive Leaf Extract Rich in Polyphenols Promotes Apoptosis in Cervical Cancer Cells by Upregulating p21(Cip/WAF1) Gene Expression. Nutrition and Cancer, 1-14. https://doi.org/10.1080/01635581.2018.1559934

[42] Zheng, J., Wei, J.T., Liu, J.F. and Liu, Y.W. (2016) Research Progress on Biological Activities of Olea europaea Leaf Extract. China Journal of Chinese Materia Medica, 41, 613-618.

[43] Azmi, A.S., Bhat, S.H. and Hadi, S. (2005) Resveratrol-Cu (II) Induced DNA Breakage in Human Peripheral Lymphocytes: Implications for Anticancer Properties. FEBS Letters, 579, 3131-3135. 